\title{
Risk Factors for Predicting Osteoporosis in Patients Who Receive Thyrotropin Suppressive Levothyroxine Treatment for Differentiated Thyroid Carcinoma
}

\author{
Diferansiye Tiroid Kanserli Tirotropin Süpresif Levotiroksin Tedavisi Alan Hastalarda \\ Osteoporozu Öngören Risk Faktörleri
}

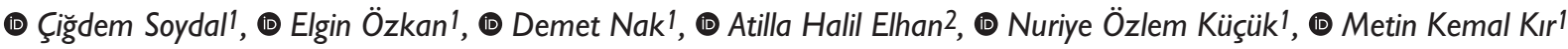

IAnkara University Faculty of Medicine, Department of Nuclear Medicine, Ankara, Turkey

${ }^{2}$ Ankara University Faculty of Medicine, Department of Biostatistics, Ankara, Turkey

\begin{abstract}
Objectives: Endogenous hyperthyroidism accelerates bone turnover and shortens the normal bone remodeling cycle, which results in reduced bone density. It is estimated that suppressive levothyroxine (LT4) therapy also decreases bone density. The aim of this study was to define risk factors for osteoporosis development in patients under thyrotropin-stimulating hormone (TSH) suppressive treatment for differentiated thyroid cancer (DTC).

Methods: Patients with a diagnosis of low or intermediate risk group DTC according to the American Thyroid Association 2015 guidelines and who have been receiving LT4 suppression therapy and were physically fit to undergo femur and lumbar vertebra bone density study were included in the study. Patients lacking information on demographic data, medical history, preoperative thyroid hormone status, or routine follow-up data were excluded from the study. A study form consisting of patient information on possible risk factors for osteoporosis such as gender, age, menopausal status, smoking, family history of osteoporosis, preoperative thyroid hormone status, postoperative hypoparathyroidism history, mean serum TSH levels, and duration of TSH suppression was created and filled out for each participant. Bone mineral densitometries of the femur and lumbar vertebrae were measured along with serum vitamin $D$ and parathyroid hormone levels.

Results: During TSH suppression (mean $7.2 \pm 4.5$ years, range: $1-26)$, osteoporosis was detected in $89(9.6 \%)$ patients. The mean time to develop osteoporosis was significantly different in patients with or without a family history of osteoporosis $(15.3 \pm 0.4$ versus $20.3 \pm 0.6$ years; $p=0.002)$. Similarly, the mean time to develop osteoporosis for was found to be significantly shorter in postmenopausal patients than that for premenopausal women (18.6 \pm 0.7 versus $20.4 \pm 0.4$ years; $p<0.001)$. Male gender $(p<0.001)$, a family history of osteoporosis $(p=0.001)$ and menopausal state $(p<0.001)$ were identified as independent predictive factors for developing osteoporosis.

Conclusion: Postmenopausal women, men, and patients with a family history who receive TSH-suppression treatment have a tendency to develop osteoporosis.
\end{abstract}

Keywords: Differentiated thyroid carcinoma, osteoporosis, thyroid-stimulating hormone suppression treatment

\section{Öz}

Amaç: Endojen hipertiroidi kemik turn-overini hızlandırır ve normal kemik remodeling döngüsünü kısaltır, bu da azalmış kemik yoğunluğuyla sonuçlanır. Süpresif levotiroksin (LT4) tedavisinin de kemik yoğunluğunu azalttığı düşünülmektedir. Bu çalışmada, diferansiye tiroid kanseri (DTK) için tirotropin-stimüle edici hormon (TSH) süpresif tedavi altındaki hastalarda osteoporoz gelişimi için risk faktörlerinin tanımlanması amaçlanmışır.

Address for Correspondence: Çiğdem Soydal MD, Ankara University Faculty of Medicine, Department of Nuclear Medicine, Ankara, Turkey Phone: +90 3125956732 E-mail: csoydal@yahoo.com ORCID ID: orcid.org/0000-0002-6199-8551

Received: 17.04.2019 Accepted: 29.05.2019

${ }^{\circ}$ Copyright 2019 by Turkish Society of Nuclear Medicine

Molecular Imaging and Radionuclide Therapy published by Galenos Yayınevi. 
Yöntem: Amerikan Tiroid Derneği 2015 rehberine göre düşük veya orta riskli DTK tanısı ile takipli, LT4 süpresyon tedavisi alan; bazal tedavi sonrası rutin klinik takip bilgilerine ulaşılan; hasta dahil etme formu doldurmak için gerekli ve yeterli demografik ve medikal takip bilgileri bulunan; genel durumu femur ve lumbal vertebra kemik dansitometri çalışması yapılması için uygun olan hastalar çalışmaya dahil edildi. Osteoporoz için olası risk faktörleri olan cinsiyet, yaş, menopoz durumu, sigara, ailede osteoporoz hikayesi, preoperatif tiroid hormon durumu, postoperatif hipoparatiroidi hikayesi, ortalama serum TSH düzeyi ve TSH süpresyon süresini içeren bir hasta dahil etme formu dolduruldu. Dahil edilen hastalara bu aşamada femur boynu ve lumbal vertebralardan kemik mineral dansitometrisi yapıldı, serum D vitamin ve parathormon düzeylerine bakıldı.

Bulgular: Ortalama TSH süpresyon süresi 7,2 $\pm 4,5$ (aralı: 1-26) yıl idi, hastaların 89'unda (\%9,6) osteoporoz saptandı. Postmenopozal olgularda osteoporoz gelişmesine kadar geçen ortalama süre premenopozal olgulardan anlamlı şekilde kısaydı $(18,6 \pm 0,7$ 'ye karşın $20,4 \pm 0,4$ yl; $p<0,001)$. Erkek cinsiyet $(p<0,001)$, aile hikayesi $(p=0,001)$ ve menopoz durumu $(p<0,001)$ osteoporoz gelişimi için bağımsız risk faktörleri olarak saptandı. Sonuç: TSH süpresyon tedavisi alan postmenopozal kadınlar, erkek ve aile öyküsü olan hastalar osteoporoz gelişimine eğilim göstermektedir. Anahtar kelimeler: Diferansiye tiroid karsinomu, osteoporoz, tiroid-stimüle edici hormon süpresyon tedavisi

\section{Introduction}

Differentiated thyroid carcinoma (DTC) is the most common endocrine neoplasia. Although the incidence of DTC is increasing its mortality rate remains stable $(1,2)$. After initial treatment with a thyroidectomy with/without radioiodine treatment, patients are treated with levothyroxine (LT4) therapy to suppress thyrotropin-stimulating hormone (TSH) since suppression of serum TSH levels reduces tumor recurrence rates (3).

Endogenous hyperthyroidism has been shown to reduce bone density because hyperthyroidism accelerates bone turnover and shortens the normal bone remodeling cycle (4). For this reason, suppression LT4 therapy might cause a decrease in bone density. Considering the long life expectancy for DTC patients, treatment related comorbidities could affect their quality of life.

Although several studies have been designed to explore the correlation between bone density changes and LT4 treatment, conflicting findings have been reported $(4,5)$. Most of the reported studies have included small number of patients, and despite this limitation bone density seems to decrease in at least some DTC patients. In this large series, we analyzed DTC patients' bone density after considering several demographic features, comorbidities, and treatment-related risk factors. In our analysis, we aimed to define additional risk factors for developing osteoporosis in patients who received TSH-suppressive LT4 treatment for DTC.

\section{Materials and Methods}

\section{Patients}

This study included prospective and retrospective components and was approved by the Institutional Ethical Committee of Ankara University Medical Faculty (approval number: 11-489-16). After receiving informed consent for the prospective component, patient inclusion was continued for the period between June 2016 and Jan 2018. All patients had received radioiodine treatment for DTC in Ankara University Medical Faculty Department of Nuclear Medicine. Patient inclusion criteria were based on several parameters: (1) low or intermediate risk group DTC diagnosis according to the American Thyroid Association (ATA) 2015 guidelines; (2) receiving LT4 suppression therapy after initial treatment; (3) available routine followup data after initial therapy; (4) known preoperative thyroid hormone status; (5) sufficient and available demographic and medical history data to fill-in the study form; and (6) be physically fit enough to undergo a femur and lumbar vertebra bone density study (6).

\section{Data Generation}

A study form including information on possible risk factors for osteoporosis such as gender, age, menopausal status, smoking, family history of osteoporosis, preoperative thyroid hormone status, postoperative hypoparathyroidism history, mean serum TSH levels, and duration of TSH suppression was created and filled out. Mean serum TSH levels were calculated from at least two serum TSH measurements per year, excluding endogenous or exogenous short duration stimulated TSH levels. The duration of TSH suppression was calculated as the interval between TSH-suppression LT4 treatment initiation and the date of patient inclusion. After selection of patients, bone mineral densitometries of the femur and lumbar vertebrae, serum vitamin $D$, and parathyroid hormone measurements were performed. T and $Z$ scores of the femur and lumbar vertebrae were used for analysis. The presence of osteoporosis was accepted as T scores $<-2.5$. In patients who already had osteoporosis at the time of study initiation, the date of osteoporosis diagnosis was retrospectively obtained from patient files. 


\section{Statistical Analysis}

The differences in proportions between groups were compared by using chi-square test. The survival estimations were performed using the method of Kaplan-Meier algorithm, and the comparison between groups was evaluated with the log-rank test. Multiple Cox regression proportional hazard model was used to determine independent predictors of osteoporosis development (7). $p$ value less than 0.05 was considered as significant. SPSS version 20.0 (IBM, Chicago, Illinois, USA) was used for statistical analyses.

\section{Results}

\section{Patients}

A total of 929 patients (813 female, 116 male, mean age: $52.33 \pm 7.2$ ) who received TSH suppression therapy for DTC were included. Patient descriptive data are presented in Table 1.
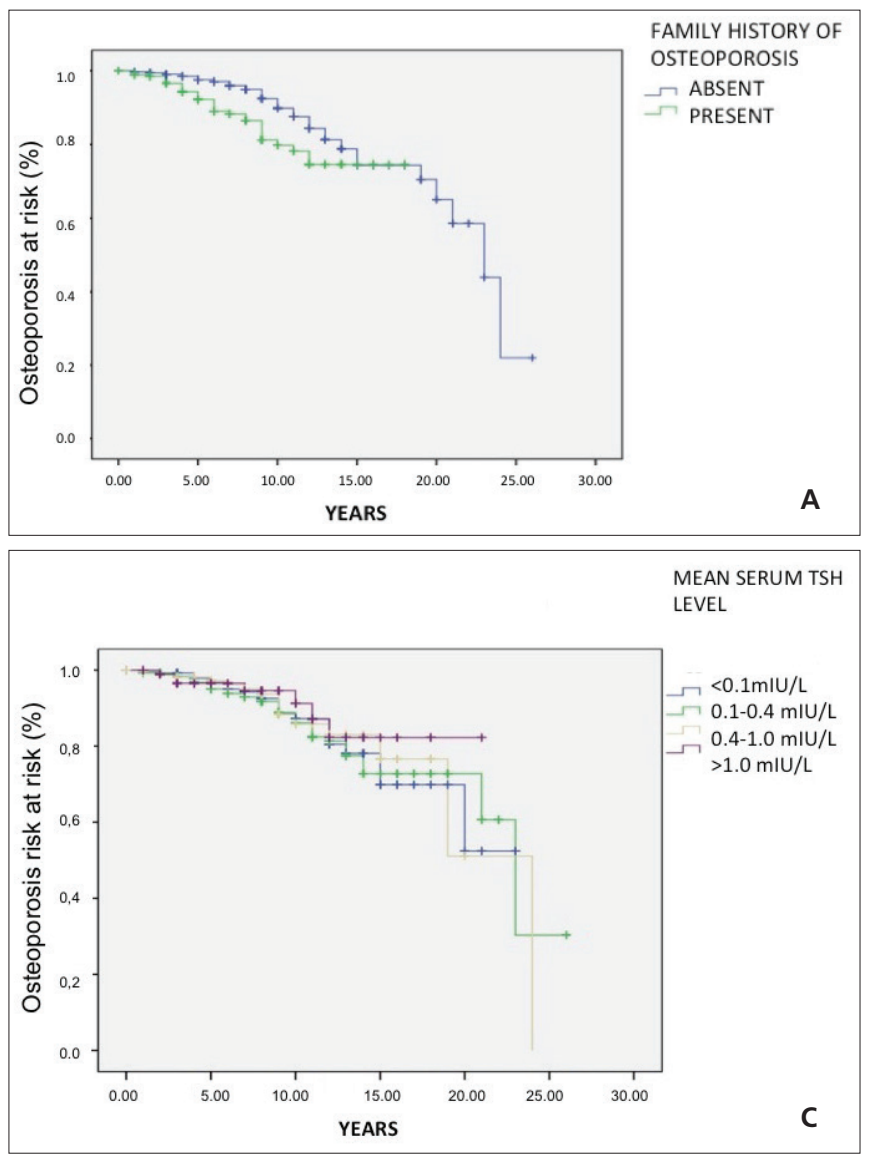

\section{Risk Factors to Development of Osteoporosis}

During TSH suppression (mean $7.2 \pm 4.5$ years, range: $1-26$ ), osteoporosis was detected in $89(9.6 \%)$ patients. The rate of osteoporosis in patients with and without a family history of osteoporosis was $13 \%$ and $8 \%$, respectively. Osteoporosis detection rates were calculated as $0.6 \%, 15 \%$, and $12 \%$ in premenopausal and postmenopausal women and men, respectively. Preoperative hyperthyroidism was found to be significantly correlated with the presence of osteoporosis based on chi-squared analysis with 15\% versus $8 \%(p=0.003)$; however, this significance was lost in multivariate Cox regression analysis. Although mean serum TSH levels were not significant factors for the presence of osteoporosis, osteoporosis detection rates seem to decrease in patients with TSH levels $>0.4 \mathrm{mIU} / \mathrm{L}$. Osteoporosis rates for different risk groups are summarized in Table 2.

The mean time to develop osteoporosis for patients with and without a family history of osteoporosis was significantly different $(15.3 \pm 0.4$ versus $20.3 \pm 0.6$ years; $\mathrm{p}=0.002$ ). Similarly, the mean time to develop osteoporosis
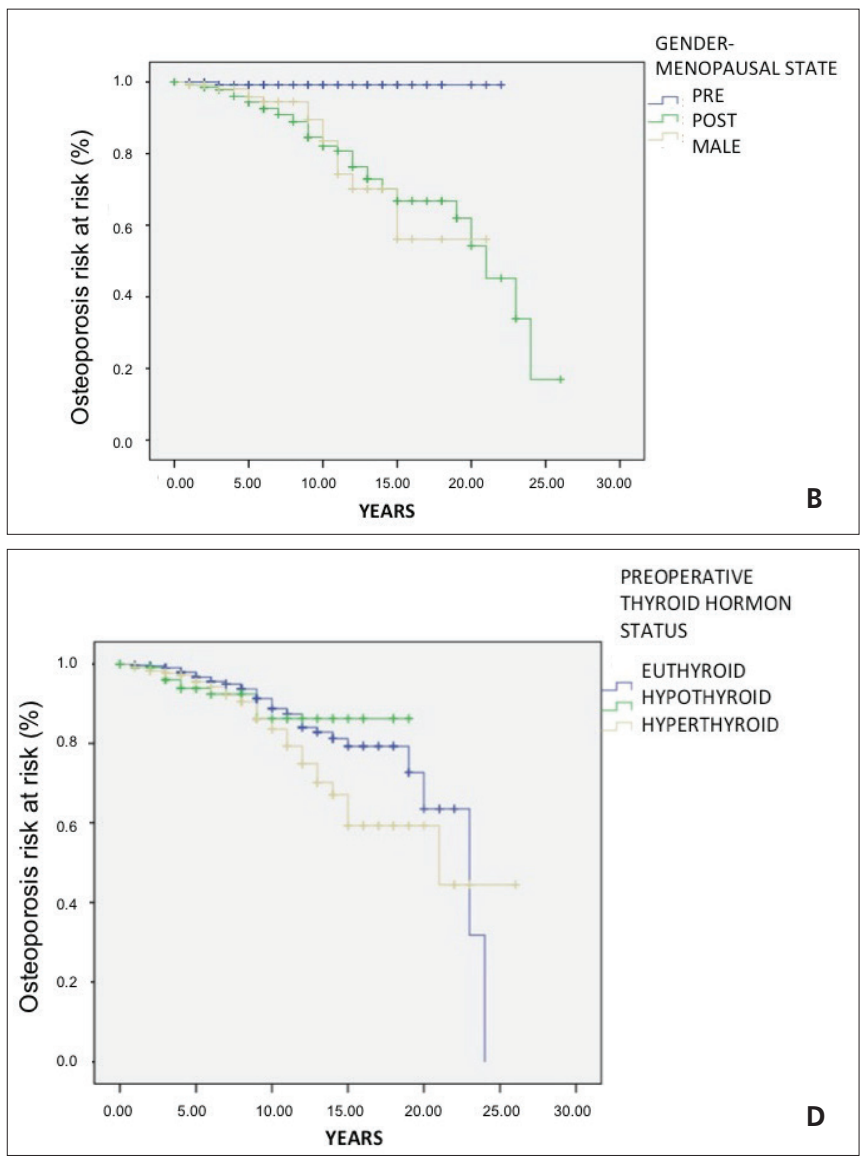

Figure 1. A, B, C, D) Kaplan-Meier curve for developing osteoporosis according to different risk groups TSH: Thyrotropin-stimulating hormone 
Table 1. Descriptive data of patients

\begin{tabular}{ll}
\hline Parameter & $\mathbf{n}(\%)$ \\
\hline Gender & \\
F & $813(87.5)$ \\
M & $116(12.5)$ \\
Menopausal state & \\
Premenopausal & $321(39.0)$ \\
Postmenopausal & $492(61.0)$ \\
Smoking & \\
Smoker & $268(28.8)$ \\
Nonsmoker & $661(71.2)$ \\
Family history of osteporosis & \\
Present & $266(28.6)$ \\
Absent & $663(71.4)$ \\
Preoperative thyroid hormone status & \\
Hypothyroid & $114(12.3)$ \\
Euthyroid & $581(62.5)$ \\
Hyperthyroid & $234(25.2)$ \\
Postoperative hypoparathyroidism & \\
Present & $343(36.9)$ \\
Absent & $586(63.1)$ \\
Mean serum TSH level (mIU/mL) & \\
$<0.1$ & $178(196(11.3)$ \\
$0.1-0.4$ & \\
$0.4-1.0$ & \\
$>1.0$ & \\
\hline F: & \\
\hline
\end{tabular}

F: Female, M: Male, n: Number, TSH: Thyrotropin-stimulating hormone

was found to be significantly shorter in postmenopausal patients as compared to premenopausal women (18.6 \pm 0.7 versus $20.4 \pm 0.4$ years; $p<0.001$ ). The mean time to develop osteoporosis according to patient characteristics is shown in Table 3. The mean time to develop osteoporosis among patient groups according to risk factors was not significant in Kaplan-Meier analysis ( $p>0.05)$. Kaplan-Meier curves for different groups are presented in Figures 1A, 1B, 1C, 1D.

Using the Cox proportional hazards regression analysis, male gender [hazard ratio (HR): $20.510,95 \%$ confidence interval (Cl): 4.644-90.579, $\mathrm{p}<0.001]$, family history of osteoporosis (HR: 2.215, 95\% Cl: 1.365-3.308, p=0.001) and menopausal state (post menopausal: HR: 18.488, 4.534-75.389, $p<0.001$; HR: 20.510, 4.644-90.579, $p<0.001$ ) were identified as independent predictive factors for developing osteoporosis (Table 4). According to multiple Cox regression proportional hazard analysis, other risk factors were not found to be significant ( $p>0.05)$.
Table 2. Osteoporosis rates of different groups

\begin{tabular}{|c|c|c|}
\hline Parameter & $\begin{array}{l}\text { Osteoporosis } \\
\text { rate, }(n)\end{array}$ & $p$ value \\
\hline \multicolumn{3}{|l|}{ Gender } \\
\hline $\mathrm{F}$ & $9 \%(74)$ & \multirow{2}{*}{0.330} \\
\hline M & $12 \%(15)$ & \\
\hline \multicolumn{3}{|c|}{ Menopausal state } \\
\hline Premenopausal & $0.6 \%(2)$ & \multirow{2}{*}{0.001} \\
\hline Postmenopausal & $15 \%(72)$ & \\
\hline \multicolumn{3}{|l|}{ Smoking } \\
\hline Smoker & $11 \%(29)$ & \multirow{2}{*}{0.287} \\
\hline Non-smoker & $9 \%(60)$ & \\
\hline \multicolumn{3}{|c|}{ Family history of osteporosis } \\
\hline Present & $18 \%(61)$ & \multirow{2}{*}{0.036} \\
\hline Absent & $8 \%(28)$ & \\
\hline \multicolumn{3}{|c|}{ Preoperative thyroid hormone status } \\
\hline Hypothyroid & $8 \%(9)$ & \multirow{3}{*}{0.012} \\
\hline Euthyroid & $8 \%(45)$ & \\
\hline Hyperthyroid & $15 \%(35)$ & \\
\hline \multicolumn{3}{|c|}{ Postoperative hypoparathyroidism } \\
\hline Present & $9 \%(30)$ & \multirow{2}{*}{0.667} \\
\hline Absent & $10 \%(59)$ & \\
\hline \multicolumn{3}{|c|}{ Mean serum TSH level (mIU/mL) } \\
\hline$<0.1$ & $10 \%(25)$ & \multirow{4}{*}{0.559} \\
\hline $0.1-0.4$ & $11 \%(28)$ & \\
\hline $0.4-1.0$ & $8 \%(29)$ & \\
\hline$>1.0$ & $7 \%(17)$ & \\
\hline
\end{tabular}

F: Female, M: Male, n: Number, TSH: Thyrotropin-stimulating hormone

\section{Discussion}

It is considered that remnant DTC cells behave in a manner similar to benign thyrocytes from which they originated. TSH stimulates the number, size and activity of thyrocytes (8). The rationale for this approach was based on observations that the incidence of thyroid cancer is correlated with serum TSH levels in the normal population (9). Hence, the primary aim of TSH suppression therapy is to lower endogenous TSH levels to reduce the risk of disease recurrence.

In the literature, different outcomes have been reported concerning the benefits of long-term TSH suppression in DTC patients. Lower serum TSH levels have been shown to be an independent predictor for disease progression in patients with a high risk of tumor recurrence. Interestingly, a similar effect has not been demonstrated on patients with stage 1 or 2 disease (10). Moreover, a meta-analysis including 10 studies did not demonstrate any benefits 
Table 3. The mean time to develop osteoporosis according to patient characteristics

\begin{tabular}{|c|c|c|c|}
\hline Parameter & & $\begin{array}{l}\text { Time to develop osteoporosis } \\
\text { (years, mean } \pm \mathrm{SD}, 95 \% \mathrm{Cl} \text { ) }\end{array}$ & $p$ value \\
\hline \multirow{2}{*}{ Gender } & $\mathrm{F}$ & $20.2 \pm 0.7,18.9-21.6$ & \multirow{2}{*}{0.2} \\
\hline & M & $16.7 \pm 1.0,14.5-18.8$ & \\
\hline \multirow{2}{*}{ Menopausal state } & Pre & $20.4 \pm 0.4,19.6-21.2$ & \multirow{2}{*}{$<0.001$} \\
\hline & Post & $18.6 \pm 0.7,17.2-20.2$ & \\
\hline \multirow{2}{*}{ Smoking } & No & $20.7 \pm 0.8,19.2-22.3$ & \multirow{2}{*}{0.27} \\
\hline & Yes & $18.9 \pm 0.9,17.1-20.6$ & \\
\hline \multirow{2}{*}{ Family history } & No & $20.3 \pm 0.7,18.9-21.7$ & \multirow{2}{*}{0.002} \\
\hline & Yes & $15.3 \pm 0.4,14.4-16.1$ & \\
\hline \multirow{3}{*}{ Preoperative thyroid hormone status } & Euthyroid & $23.0 \pm 2.2,18.7-27.3$ & \multirow{3}{*}{0.09} \\
\hline & Hypothyroid & $22.2 \pm 2.3,17.2-25.5$ & \\
\hline & Hyperthyroid & $21.0 \pm 1.9,19.2-26.8$ & \\
\hline \multirow{2}{*}{ Postoperative hypoparathyroidism } & No & $23.0 \pm 2.0,18.9-27.0$ & \multirow{2}{*}{0.9} \\
\hline & Yes & $22.3 \pm 1.8,16.5-24.2$ & \\
\hline \multirow{4}{*}{ Mean serum TSH level } & $<0.1$ & $21.0 \pm 1.2,18.6-23.3$ & \multirow{4}{*}{0.43} \\
\hline & $0.1-0.4$ & $21.5 \pm 2.1,19.2-22.5$ & \\
\hline & $0.4-1.0$ & $23.0 \pm 2.2,18.6-27.3$ & \\
\hline & $>1.0$ & $23.0 \pm 1.9,19.1-26.8$ & \\
\hline
\end{tabular}

Cl: Confidence interval, TSH: Thyrotropin-stimulating hormone, SD: Standard deviation

Table 4. Independent predictive factors of developing osteoporosis

\begin{tabular}{llllll} 
& B & SE & P & HR & 95\% CI for HR \\
\hline Menopausal state & & & & & \\
Post menopausal & 2.917 & 0.717 & $<0.001$ & 18.488 & $4.534-75.389$ \\
Male & 3.021 & 0.758 & $<0.001$ & 20.510 & $4.644-90.579$ \\
Family history & 0.754 & 0.226 & 0.001 & 2.125 & $1.365-3.308$ \\
\hline
\end{tabular}

HR: Hazard ratio, SE: Standard error, Cl: Confidence interval

from TSH suppression (11). The National Thyroid Cancer Cooperative Study Group Registry published a study including 1548 patients. In contrast to our study, in their analysis, TSH suppression improved overall survival in stage 2 patients (12). Similarly, Hovens et al. (13) have reported results of 366 patients treated with total thyroidectomy followed by radioiodine treatment. They found that serum TSH levels $>4.5 \mathrm{mU} / \mathrm{L}$ was an independent predictor for death, and TSH levels $>2 \mathrm{mU} / \mathrm{L}$ were also associated with DTC-related deaths and recurrence in patients with T1-3, M0 tumors. Also, Pujol et al. (14) reported that suppressed serum TSH levels were associated with an increase in relapse-free survival in patients with DTC.

Controversial results based on these analyses have led to discussions about optimal TSH level and duration of suppression for low-intermediate risk group patients with respect to therapy-related side effects. Thyroid hormones act directly on the skeleton, and endogenous hyperthyroidism is known to be related with a high risk of osteoporosis (15). Known risks of iatrogenic overt or subclinical hyperthyroidism are osteoporosis, osteopenia, and/or atrial fibrillation. For this reason, slightly subnormal or normal TSH levels are recommended for long term periods (16). Two cohort studies have demonstrated that postmenopausal DTC patients with fully suppressed TSH levels have a high risk of osteoporosis $(17,18)$. In our study, we aimed to analyze additional risk factors for developing osteoporosis in a large cohort. A family history of osteoporosis and menopausal status were found to be significant factors favoring osteoporosis development. The presence of preoperative hyperthyroidism could also be another risk factor. Interestingly, we could not find any significant correlation between mean serum TSH levels and presence of osteoporosis. However, osteoporosis detection rates tend to decrease in patients with mean TSH levels $>0.4 \mathrm{mIU} / \mathrm{L}$. 
Another interesting finding of our analysis was that male patients who received TSH suppression therapy were found to have a 20-fold increase in developing osteoporosis as compared to premenopausal women. Most studies have included only female patients for osteoporosis analysis. Reverter et al. (19) analyzed bone mineral densities and bone fractures in male patients receiving long-term TSH suppressive therapy. They compared bone mineral density and bone turnover parameters from 33 DTC patients with age- and body mass index-matched control groups. They did not find any significant differences between bone turnover parameters, including the $T$ and $Z$ scores, between groups. We could not compare our study parameters with an agematched group. However, the number of included male patients in this study was higher than that in the previous study. A total of 66 patients and 67 controls were included in a recent meta-analysis on the effects of TSH suppression in men. The authors did not find any significant correlation between TSH suppression and lower BMD values in men (20). For this reason, the osteoporosis rate in male patients receiving TSH suppression therapy needs further clarification with prospective randomized control studies.

The ATA 2015 guidelines recommend 0.1-0.5 mU/L levels as an initial TSH goal for low-risk group patients with indeterminate or incomplete response as well as for intermediate risk group patients based on data on this subject. The guide recommends continuation therapy with 0.5-2.0 $\mathrm{mU} / \mathrm{L}$ levels for low and intermediate risk group patients with excellent response. It is reasonable for clinicians to consider disease stage, response to initial treatment, and personal risk factors to develop osteoporosis in order to personalize a patient's TSH suppression therapy. The risk of disease recurrence and TSH suppression-related risks should be balanced. Postmenopausal women, men, and patients with a family history of osteoporosis have a high rate of osteoporosis under TSH-suppression LT4 treatment. Preoperative hyperthyroidism and mean serum TSH levels seem to be possible predictors of developing osteoporosis, although not statistically significant.

\section{Conclusion}

The current data suggest that personalized TSH suppression treatment, based on DTC risk group and patient-related risk factors to develop osteoporosis, might be beneficial.

Postmenopausal women, men, and patients with a family history who are under TSH-suppression treatment have a high rate of osteoporosis. Thus, male or postmenopausal female patients with low/intermediate risk DTC and a family history of osteoporosis should be closely followedup.

\section{Ethics}

Ethics Committee Approval: This study included prospective and retrospective components and was approved by the Institutional Ethical Committee of Ankara University Medical Faculty (approval number: 11-489-16).

Informed Consent: Consent form was filled out by all participants.

Peer-review: Externally peer-reviewed.

\section{Authorship Contributions}

Surgical and Medical Practices: Ç.S., D.N., E.Ö., M.K.K., Concept: Ç.S., Design: Ç.S., M.K.K., E.Ö., N.Ö.K., Data Collection or Processing: D.N., Ç.S., A.H.E., Analysis or Interpretation: A.H.E., Ç.S., Literature Search: D.N., Ç.S., Writing: Ç.S., D.N., E.Ö.

Conflict of Interest: No conflict of interest was declared by the authors.

Financial Disclosure: The authors declared that this study received no financial support.

\section{References}

1. Brito JP, Davies $L$. Is there really an increased incidence of thyroid cancer? Curr Opin Endocrinol Diabetes Obes 2014;21:405-408.

2. Makazlieva T, Vaskova O, Majstorov V. Etiopathogenesis of Differentiated Thyroid Carcinomas. Open Access Maced J Med Sci 2016;15:517-522.

3. Reverter JL, Holgado S, Alonso N, Salinas I, Granada ML, Sanmartí A. Lack of deleterious effect on bone mineral density of long-term thyroxine suppressive therapy for differentiated thyroid carcinoma. Endocr Relat Cancer 2005;12:973-981.

4. Kim CW, Hong S, Oh SH, Lee JJ, Han JY, Hong S, Kim SH, Nam M, Kim YS. Change of Bone Mineral Density and Biochemical Markers of Bone Turnover in Patients on Suppressive Levothyroxine Therapy for Differentiated Thyroid Carcinoma. J Bone Metab 2015;22:135-141.

5. Vera L, Gay S, Campomenosi C, Paolino S, Pera G, Monti E, Mortara L, Seriolo B, Giusti M. Ten-year estimated risk of bone fracture in women with differentiated thyroid cancer under TSH-suppressive levothyroxine therapy. Endokrynol Pol 2016;67:350-358.

6. Haugen BR, Alexander EK, Bible KC, Doherty GM, Mandel SJ, Nikiforov YE, Pacini F, Randolph GW, Sawka AM, Schlumberger M, Schuff KG, Sherman SI, Sosa JA, Steward DL, Tuttle RM, Wartofsky L. 2015 American Thyroid Association Management Guidelines for Adult Patients with Thyroid Nodules and Differentiated Thyroid Cancer: The American Thyroid Association Guidelines Task Force on Thyroid Nodules and Differentiated Thyroid Cancer. Thyroid 2016;26:1-133.

7. David W. Hosmer Jr, Stanley Lemeshow, Susanne May. Applied Survival Analysis: Regression Modeling of Time-to-Event Data, 2nd Edition. Wiley Series in Probability and Statistics. Wiley 2008:416.

8. McLeod DS. Thyrotropin in the development and management of differentiated thyroid cancer. Endocrinol Metab Clin North Am 2014;43:367-383.

9. Freudenthal B, Williams GR. Thyroid Stimulating Hormone Suppression in the Long-term Follow-up of Differentiated Thyroid Cancer. Clin Oncol ( $R$ Coll Radiol) 2017;29:325-328.

10. Cooper DS, Specker B, Ho M, Sperling M, Ladenson PW, Ross DS, Ain KB, Bigos ST, Brierley JD, Haugen BR, Klein I, Robbins J, Sherman SI, Taylor T, Maxon HR. Thyrotropin suppression and disease progression in patients 
with differentiated thyroid cancer: results from the National Thyroid Cancer Treatment Cooperative Registry. Thyroid 1998;8:737-744.

11. McGriff NJ, Csako G, Gourgiotis L, Lori C G, Pucino F, Sarlis NJ. Effects of thyroid hormone suppression therapy on adverse clinical outcomes in thyroid cancer. Ann Med 2002;34:554-564.

12. Jonklaas J, Sarlis NJ, Litofsky D, Ain KB, Bigos ST, Brierley JD, Cooper DS, Haugen BR, Ladenson PW, Magner J, Robbins J, Ross DS, Skarulis M, Maxon HR, Sherman SI. Outcomes of patients with differentiated thyroid carcinoma following initial therapy. J Thyroid 2006;16:1229-1242.

13. Hovens GC, Stokkel MP, Kievit J, Corssmit EP, Pereira AM, Romijn JA, Smit JW. Associations of serum thyrotropin concentrations with recurrence and death in differentiated thyroid cancer. J Clin Endocrinol Metab 2007;92:2610-2615

14. Pujol P, Daures JP, Nsakala N, Baldet L, Bringer J, Jaffiol C. Degree of thyrotropin suppression as a prognostic determinant in differentiated thyroid cancer. J Clin Endocrinol Metab 1996;81:4318-4323.

15. Bassett JH, Williams GR. Role of Thyroid Hormones in Skeletal Development and Bone Maintenance. Endocr Rev 2016;37:135-187.
16. Biondi B, Filetti S, Schlumberger M. Thyroid-hormone therapy and thyroid cancer: a reassessment. Nat Clin Pract Endocrinol Metab 2005;1:32-40.

17. Wang LY, Smith AW, Palmer FL, Tuttle RM, Mahrous A, Nixon IJ, Patel SG, Ganly I, Fagin JA, Boucai L. Thyrotropin suppression increases the risk of osteoporosis without decreasing recurrence in ATA low-and intermediate-risk patients with differentiated thyroid carcinoma. Thyroid 2015;25:300-307.

18. Turner MR, Camacho X, Fischer HD, Austin PC, Anderson GM, Rochon PA, Lipscombe LL. Levothyroxine dose and risk of fractures in older adults: nested case-control study. BMJ 2011;342:2238.

19. Reverter JL, Colomé E, Holgado S, Aguilera E, Soldevila B, Mateo L, Sanmartí A. Bone mineral density and bone fracture in male patients receiving long-term suppressive levothyroxine treatment for differentiated thyroid carcinoma. Endocrine 2010;37:467-472.

20. Yoon BH, Lee Y, Oh HJ, Kim SH, Lee YK. Influence of Thyroid-stimulating Hormone Suppression Therapy on Bone Mineral Density in Patients with Differentiated Thyroid Cancer: A Meta-analysis. J Bone Metab 2019;26:51-60. 